\title{
nature
}

\section{Human cloning requires a moratorium, not a ban}

Unprecedented media coverage of cloning highlights a genuine need for reflection by society. Research into animal cloning need not be hindered, but a declared moratorium on human cloning is desirable.

T he history of science suggests that efforts to block its development are misguided and futile. Yet, following the news that scientists in Scotland have successfully cloned a lamb from an udder cell taken from an adult sheep (Nature 385, 810-813; 1997), calls for an outright ban on human cloning have come from bodies and individuals as diverse as the Vatican, the US Biotechnology Industry Organization, and Joseph Rotblat, the 1995 winner of the Nobel peace prize. Politicians have not been deaf. Countries already banning the procedure have been smugly pointing this out. Other places - such as New York state — have seen hastily drafted bills seeking the same goal.

The reaction of the scientific community has been justifiable concern that such moves are in danger of throwing out the baby with the bathwater (see pages 8-9). Few people indeed would condone the idea of human cloning for political or aesthetic reasons, or even out of sheer curiosity. But there are purposes for which aspects of human cloning could technically be highly desirable - for example, in order to generate skin grafts for burn victims, or other 'spare-part' provision.

The arguments in favour of human cloning need to be heard, but now is also certainly a time for wide-ranging circumspection. True, recent developments may not represent an overnight invitation to the moral collapse of the human race that some critics predict. Furthermore, there are many technical reasons to believe that the cloning of adult humans will remain unfeasible for years to come. But there is no escaping the legitimate concerns arising from the fact that a lamb cutely named Dolly represents an irreversible development of breathtaking implications.

Circumspection requires the avoidance of both precipitous action based on panic, and inaction based on complacency. The challenge facing legislators, as in so many aspects of modern science in general, and modern genetics in particular, is to chart a way forward that balances two requirements. One is to maintain the maximum freedom of scientific enquiry, while recognizing that this is not necessarily an inalienable right. The second is to respect the commonly perceived dignity of human life, while accepting that, whatever some philosophers and religious leaders may say, this is not inevitably compromised by human cloning.

Experience in striking such a balance in recent years has been mixed, particularly in the United States. There, initial reaction to the challenge of recombinant-DNA technology was exemplary. Both the industrial promises and potential environmental threats of the new technology were recognized promptly. A brief initial moratorium, called in 1976 by scientists such as Paul Berg and colleagues to take stock of the situation, was soon followed by strict regulation. But this was steadily loosened as US society became increasingly confident of its ability to understand and handle the potential abuses and dangers involved.

In contrast, the US record on embryo research, a prey to the aggressive zealotry of the anti-abortion movement, reveals less to be proud of. Where anti-abortionists have been able to wield their influence, in particular over the research agenda of the National Institutes of Health, they have been able to block all research in the field. But where their political ideology has discouraged interference, namely in the operations of the marketplace, they have sat on their hands, allowing biocommerce potentially to burgeon even in areas of public sensitivity. The calamitous and perverse result is that research for which it is forbidden to use public funds can now be carried out unregulated - and unmonitored - in private laboratories.

The experience with genetic engineering technology shows that an explicit moratorium can be productive. On the one hand it sends a public signal that ethical considerations are important and need to be taken into account, and allows that to happen. On the other, the fact that a moratorium is, by definition, likely to be lifted at some point indicates that further development can be anticipated.

The embryo research debate underlines a second message. While the bodies set up to regulate and monitor new developments in science must reflect a range of public opinion, the net must not be cast so wide that they are held hostage to unremitting dogmatism. An excellent model here is the all-party Select Committee on Science and Technology of Britain's House of Commons. The committee's report on human genetics, published in the summer of 1995, may have represented a compromise between the views of members of two opposing political parties. But it still had sufficient teeth to embarrass the government into setting up a broad-ranging genetics advisory panel, and the insurance industry into drawing up guidelines of good practice. Its proceedings were also a model of openness.

Perhaps the closest US model is the now-defunct Office of Technology Assessment (OTA). The inelegant posture that Congress finds itself in over embryo research, as well as the surprise with which news of the Scottish cloning experiments was greeted by the political community, highlights the political folly of eliminating the OTA. At the same time, the cloning news has shown up a limitation of the technology assessment approach: how blinkered it can be, despite the best of intentions. The chairman of one of the panels that conducted Britain's recent Technology Foresight exercise, which made no reference to the possibility of human cloning, admits candidly that this was not considered sufficiently seriously.

A moratorium on the cloning of animals would go well beyond what society needs in order to take stock. But a declared moratorium on human cloning is desirable, even though it carries with it a possibility that will worry those who wish to pursue such research: that legislators will consider the potential benefits but decide that the risks to society are too significant for it to be permitted at all. The history of technology suggests, however, that highly regulated human cloning will, after all, be found to be a tolerable way to proceed. 